\title{
Appraisal of Municipal Solid Waste Management, Its Effect and Resource Potential in A Semi-Urban City: a Case Study
}

\author{
David O. Olukanni ${ }^{1}$, Oladipupo O. Akinyinka ${ }^{2}$, Anthony N. Ede ${ }^{3}$, Isaac. I. Akinwumi ${ }^{4}$ \\ and Kolawole O. Ajanaku ${ }^{5}$ \\ 1,2,3,4 Department of Civil Engineering, Covenant University, Ota, Ogun State, Nigeria \\ ${ }^{5}$ Department of Industrial Chemistry, Covenant University, Ota, Ogun State, Nigeria
}

Correspondence should be addressed to: David O. Olukanni; david.olukanni@covenantuniversity.edu.ng

Received date: 20 September 2013; Accepted date: 26 January 2014; Published date: 15 October 2014

Academic Editor: woo kok hoong

Copyright (C) 2014. David O. Olukanni, Oladipupo O. Akinyinka, Anthony N. Ede, Isaac. I. Akinwumi and Kolawole O. Ajanaku. Distributed under Creative Commons CC-BY 3.0

\begin{abstract}
Managing municipal solid wastes (MSW) is progressively becoming a major challenge in many cities of developing nations because of rapid urbanization and rise in population. This can be described by ineffective collection methods, inadequate coverage of the collection, processing system and inappropriate disposal. This paper presents the current state of solid waste management in a semi-urban city, its associated challenges and prospects that are within. A field work that involves the characterization and types of the waste generated, and frequency of collection was carried out within the study area. Four locations where the major waste bins are located within the city were considered. A representative sample of $280 \mathrm{~kg}$ was used for the waste characterization, and the results show that about $64 \%$ of the wastes are recyclable with lots of organic waste that can be used as compost. The only dump site in the city was visited in order to obtain useful information concerning the present state of solid waste management. The study revealed that there is presently no investment made to the existing development plan to introduce a modern waste management system. The study suggests new approach that could be used by institutions and government agencies for MSW management to realize a sustainable and efficient sanitation, and possible resources generation potentials that could be harnessed from the waste stream.
\end{abstract}

Keywords: Semi-Urban City, Municipal Solid Waste, Waste Characterization, Effective Sanitation, Resources Potential.

Cite this Article as: David O. Olukanni, Oladipupo O. Akinyinka, Anthony N. Ede, Isaac. I. Akinwumi and Kolawole 0. Ajanaku (2014), " Appraisal Of Municipal Solid Waste Management, Its Effect And Resource Potential In A Semi-Urban City: A Case Study ", Journal of South African Business Research,

Vol. 2014 (2014), Article ID 705695, DOI: 10.5171/2014.705695 


\section{Introduction}

The management of solid waste has posed a serious challenge to the development of many developing nations across the globe. Factors responsible for the growth in waste generation in many modern societies are traced to increasing population that is complemented by rapid urbanization and industrialization, which has resulted into a dramatic increase in the volume of wastes generated. Other factors responsible for rate and quantity at which solid waste is generated are tied to citizens' socioeconomic status, and the type of predominant commercial activities. The unpleasant situation with regards to the collection, transportation and disposal of waste is well known but the knowledge of its hazards and good processing practices through to final disposal have been very poor. One of the observable impacts of rapidly growing urbanization, and economic development in emerging cities is witnessed in the form of heaps of municipal solid waste (MSW) in inappropriate locations (Agunwamba, 1998; 2003; Babayemi and Dauda, 2009; Olukanni and Akinyinka, 2012). Current estimates in Nigeria reveal an annual solid waste generation of 25 million tones with an urban growth exceeding $6.5 \%$ per annum. The generation rate of municipal solid wastes in Ota metropolis, a semi-urban city in Ogun State, Nigeria, has increased at a disturbing rate over the years. Babayemi and Dauda (2009) stated that the lack of technical knowhow, inadequate equipment for separation, weakness of solid waste management guidelines and compliance by people, environmental consciousness and earnings of people among others, are reasons for inefficient waste management. In addition, the heaps of domestic and industrial garbage are recognizable signs that the authorities are having problems managing these wastes.

Ota metropolis in Ogun State, South-Western Nigeria, has witnessed a rapid urbanization over the past decades providing a large market for manufacturing industries and organizations. Its population growth has led to the rapid expansion of the city which has resulted in urban sprawl and uncontrolled increase of occupancy ratios in existing housing units and infilling of vacant plots in existing residential area. However, the lack of proper and comprehensive land use planning has hindered effective sanitation, thus reeling under indiscipline and haphazard way of dumping refuse in an objectionable manner (Olukanni and Akinyinka, 2012). It is rather unfortunate, that despite the high capital investment by the State government on solid waste management, this has not brought improvements in the quality of service to the people, and lack of orientation for the residents of the municipality has also been the bane of such huge investment. Hence, the common practice among people in most parts of the city is dumping of refuse in the open. The offensive decomposing waste often attracts vermin, such as rats and flies that act as vectors which may pose severe environmental and health hazards to the people in the community. The wastes did not only kill the aesthetics of the city, but had for years posed a serious health challenge to the thousands of its inhabitants.

The general practice in the municipality has been the indiscriminate disposal of solid waste by road sides, thereby creating unsanitary environments in many parts of the metropolis. Figure 1 shows an example of the indiscriminate dumping of waste in drains and littering along road sides. In addition, waste disposal site in the municipality is faced with poorly developed dumping ground that is potentially threatening to public and environmental health. The reason for these is not farfetched, as Kyessi and Mwakalinga (2009) expressed that rapid urbanization has increased pressure on social services, most of which have not been sustainably provided to match socio-economic and demographic growth. Agunwamba (1998; 2003) stated that political, economical and sociological factors among other factors contribute to inadequate 
implemented environmental guidelines that complicate such problems.

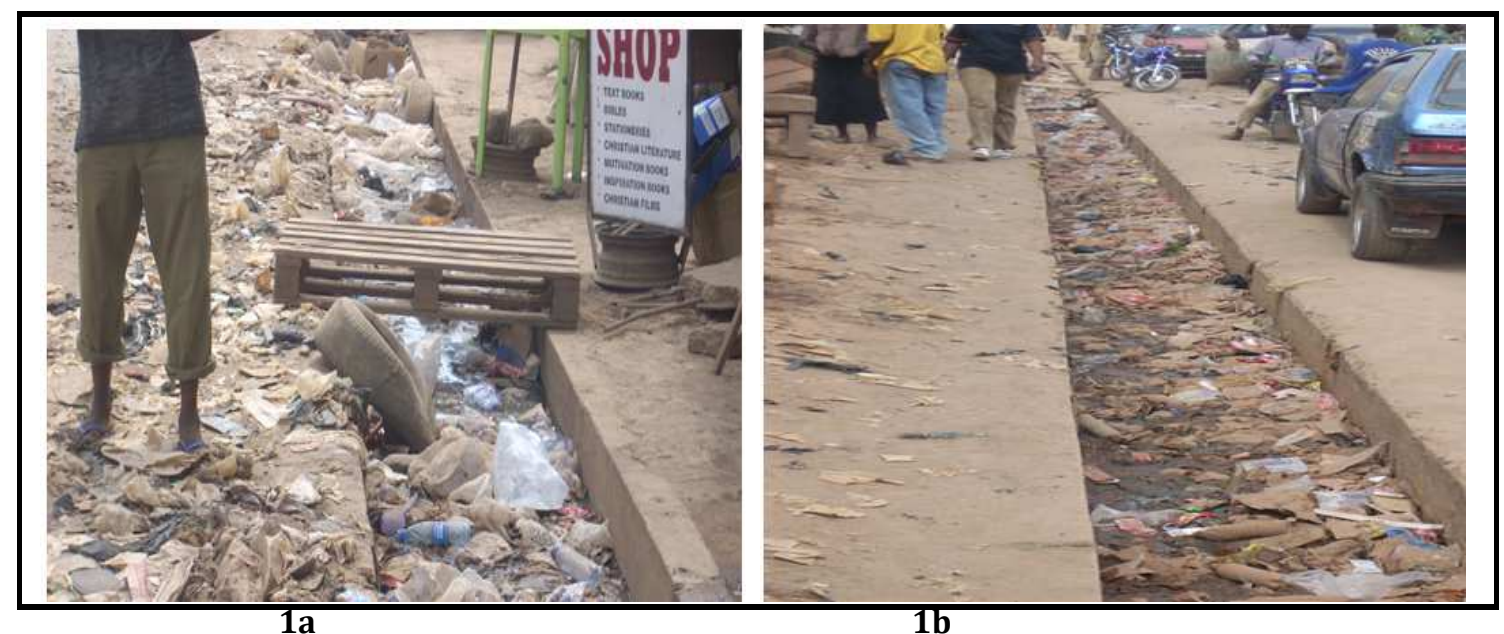

Figure 1: Indiscriminate Dumping of Waste in Drainages and Along the Road Sides

Ogwueleka (2009), Babayemi and Dauda (2009) described the solid waste management in Nigeria as being challenged with ineffective collection technique, inadequate coverage of the collection routine, and unlawful dumping of solid waste. Babayemi and Daudu (2009) also revealed in their study that there is a high rate of generation of MSW devoid of an equivalent effective expertise to handle the wastes generated. Adewumi et al. (2005) revealed the average rate of waste generation in some Nigerian cities is as follows: $\quad 0.71 \mathrm{Kg} / \mathrm{h} /$ day, $\quad 0.71 \mathrm{Kg} / \mathrm{h} /$ day, $0.60 \mathrm{Kg} / \mathrm{h} /$ day, $\quad 0.54 \mathrm{Kg} / \mathrm{h} \quad /$ day and $0.46 \mathrm{Kg} / \mathrm{h} /$ day, Ibadan in Oyo State, Ado-Ekiti in Ekiti State, Abeokuta in Ogun State, Akure in Ondo State, and Ile-Ife in Osun State, respectively.

The Federal Government of Nigeria was motivated to establish the Federal Environmental Protection Agency (FEPA) in 1988, and a national policy on the environment was formed. The objectives of the policy include: securing a quality environment that is adequate for the health and well being, increasing public consciousness, promoting understanding of the vital linkages between the environment and development, and persuading the individual and the community to participate in environmental safety and improvement efforts for all Nigerians. (FEPA, 1989 in Agunwamba, 1998). The outcome of the FEPA Act, birthed the era in which many States of the Federation within their jurisdiction, established their own waste management authorities for the safety and development of the environment. Only few States have been able to forestall the challenges of urban waste management programmes. Consequently, heeps of waste are still placed along road sides, and by road divider for days with minimal effort at getting rid of them (Akinro et al., 2012).

Right direction in the management of municipal solid waste at all phases is awaited, which is to be beneficial to the health and sustainable development, as well as the economic well-being of the community. Ogwueleka (2009) stated that a different approach is needed for developing rural areas in the management of solid waste, because most developing States have solid waste management challenges different from those found in developed countries in areas 
of composition, density, waste amount and access to waste collection, awareness and attitudes, political and economic framework. There have been a number of studies that focus attention on solid waste generation and disposal in Nigerian cities (Imam, 2008; Adefemi and Awokunmi, 2009; Abel, 2009). The predominant idea that runs through these studies cited is that they generally examined solid waste generation and disposal systems. However, there are few research works on the environmental effect, health and wealth factors associated with the management of MSW in Nigeria. The focus of this study is to identify and analyze the environmental issue, health and wealth factors linked with the management of Municipal Solid Waste (MSW), and resources that could be harnessed from the MSW generated.

\section{Materials and Method}

\section{Study Area}

Ota has the third largest concentration of industries in Nigeria (Salako, 1999). It is the capital of the Ado-Odo/Ota local government area, and it covers an area of 878 square kilometers which lies between latitude $6^{\circ} 41^{\prime} \mathrm{N}$ and $6^{\circ} 68^{\prime} \mathrm{N}$ and longitude $3^{\circ} 41^{\prime} \mathrm{E}$ and $3^{\circ} 68^{\prime} \mathrm{E}$. The LGA has an estimated residents of 527,242 (Male 261,523 and Female 265,719) (2006 Census), with about four hundred and fifty (450) towns, villages and settlements. Other towns and cities include Ado-Odo, Igbesa, Agbara, Sango-Ota, and Itele. Ota also accommodates the Canaan
Land where the mega church Winner's Chapel, renowned as the world's largest single auditorium is situated. Ota is gradually becoming a busy place because of its proximity to Lagos, thereby increasing the migration of people into it (Olukanni and Akinyinka, 2012).

\section{Field Work}

This study is both quantitative and descriptive with field works and assessment that involved the characterization of the waste from four waste bin locations. The quantitative approach allows the choice of a representative sample from among the population to be examined, which then permits an analysis that brings about inferences for the entire population under study (Akinro et al., 2012). The location of the collection points, type of waste generated, collection duration and frequency were collected. The only dump site in Ota was visited. Discussion and interviews were held with some of the residents, scavengers and key officials in order to confirm the practice and problems facing solid waste management. The city has limited the number of waste collection bin locations. Generally, there are four major waste bin locations, each located in Iganmode Grammar School, Joju Junction, Ota market and Toll Gate area. Figure 2 shows the map of Nigeria with the location of Ota Township with the four waste bin/collection points labeled for identification. 


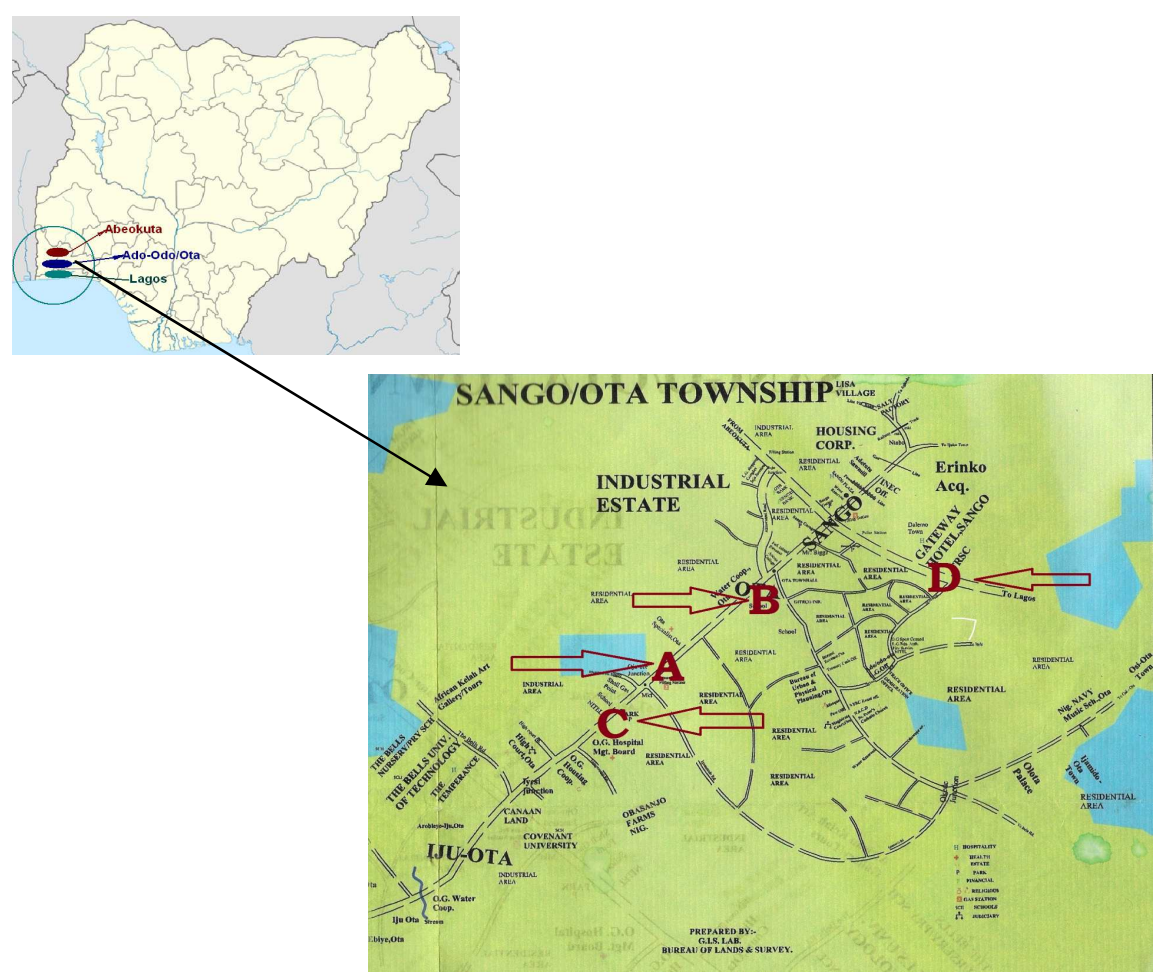

Figure 2 : A Map of Nigeria showing Ota Township and locations of the Waste collection point

The indiscriminate disposal of waste in Ota is a concern to the Ado-Odo Ota local government waste management agency, and this gave rise to the provision of waste bin along the road side for ease of generation and collection. The volume of the waste bin provided by the local government waste management authority is $7 \mathrm{~m}^{3}$. A representative sample of $280 \mathrm{~kg}$ was collected from a loaded $7 \mathrm{~m}^{3}$ waste bin and its surrounding in each of the location to represent the municipal solid waste generated. The weighing scale was used in determining the weight of solid waste collected. Glove and nose guard were used for safety measure. Thereafter, sorting of the waste was done in order to classify the waste into glass, food waste, textile, rubber, plastics, carton, paper etc., and

subsequently, the characterized waste was weighed and recorded for each of the sites. The quantity of characterized waste varies with site. Table 1 shows the description of the waste bin locations and the quantities provided at each location.

Table 1 : Waste bins location in Ota and quantities provided

\begin{tabular}{|l|l|l|}
\hline Site & Location & Quantity of bins \\
\hline A & Iganmode Grammar School. & 4 \\
\hline B & Joju Junction. & 2 \\
\hline C & Ota Market. & 3 \\
\hline D & Toll Gate. & 1 \\
\hline
\end{tabular}

David O. Olukanni, Oladipupo O. Akinyinka, Anthony N. Ede, Isaac. I. Akinwumi and Kolawole O. Ajanaku (2014), Journal of South African Business Research, DOI: 10.5171/2014.705695 
The quantity of waste bins supplied is based on the population and the activity in such area. Iganmode area has four waste bins because it is a residential/commercial area, while Ota market also has three due to the commercial activities there. Joju has two waste bins because it is also a residential area, and toll gate has only one waste bin because it is a transition point with varying population for motorist and people moving in and out of Ota. Figure 3 shows the waste collection bin at one of the locations.

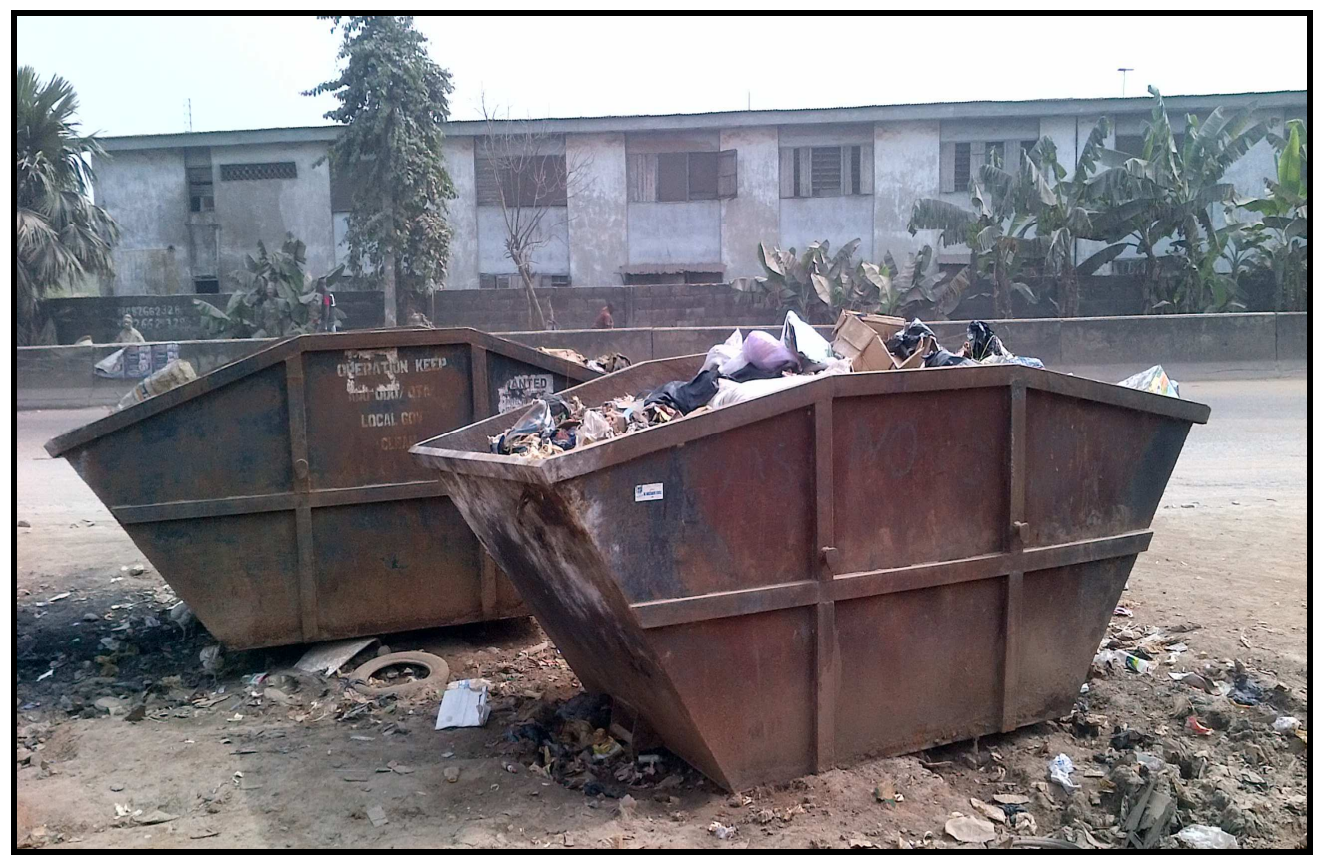

Figure 3 : Waste Collection bins provided by the Local Government at one of the locations

Some of the factors responsible for waste generation in Ota are income status of residents, education and awareness, social status, lack of facility for separation at source, and the willingness of residents to abide by the policies of government on solid waste management. The effectiveness in waste collection is largely controlled by location, ability and willingness of the waste generator to pay the tipping fee charged as initiated by both public-private partnerships.

$\begin{array}{llccc}\text { Characterization } & \text { of } & \text { Waste } & \text { Composition } & (\%) \\ \text { Characteri sation ..of ..Waste } & \text {..Compositio } & n .(\%)=\frac{\text { Weight ..of ..Waste ..Compositio }}{n .(\mathrm{kg})}\end{array}$

\section{Results}

From the interviews, personal observation and inquiries made, the local government provides waste bins for the storage of waste to reduce the indiscriminate disposal of solid waste on the road side. Tables 2-4 show the composition of the inorganic and organic wastes from the collection points.

David O. Olukanni, Oladipupo O. Akinyinka, Anthony N. Ede, Isaac. I. Akinwumi and Kolawole O. Ajanaku (2014), Journal of South African Business Research, DOI: 10.5171/2014.705695 
Table 2: Composition of inorganic and organic waste of the $280 \mathrm{~kg}$ from collection points

\begin{tabular}{|lcc|}
\hline \multicolumn{1}{c}{ LOCATION } & \multicolumn{2}{c|}{ TYPE OF WASTE } \\
\cline { 2 - 3 } Iganmode Grammar School & 60.28 & Organic (\%) \\
Joju Junction & 65.38 & 39.72 \\
Ota Market. & 63.51 & 34.62 \\
Toll Gate. & 6111 & 36.49 \\
\hline
\end{tabular}

Results in Table 2 shows that a larger proportion of the waste generated by the people of Ota is inorganic which is relatively the same over the entire sampling points.

Table 3: Representative Composition of Inorganic Waste in Ado-Odo Local Government

\begin{tabular}{|c|c|c|c|c|}
\hline LOCATION & $\begin{array}{c}\text { Iganmode Grammar } \\
\text { School Site A }\end{array}$ & $\begin{array}{c}\text { Joju Jumction Site B } \\
\text { Percentage }(\%)\end{array}$ & $\begin{array}{c}\text { Ota Market Site C } \\
\text { Percentage (\%) }\end{array}$ & $\begin{array}{l}\text { Toll Gate Site D } \\
\text { Percentage (\%) }\end{array}$ \\
\hline MATERIAL \} $&{\text { Percentage }(\%)} &{ } &{ } &{ } \\
{\hline \text { PAPER }} &{455} &{3.92} &{4.26} &{303} \\
{\hline \text { CARTON }} &{11.36} &{11.76} &{14.89} &{9.09} \\
{\hline \text { PLASTICS }} &{9.09} &{5.88} &{12.77} &{18.18} \\
{\hline \text { TEXTILE }} &{13.64} &{9.8} &{6.38} &{9.09} \\
{\hline \text { RUBBER }} &{6.82} &{5.88} &{10.64} &{12.12} \\
{\hline \text { GLASS }} &{11.36} &{15.69} &{8.51} &{21.21} \\
{\hline \text { T IN CAN }} &{455} &{7.84} &{12.77} &{12.12} \\
{\hline \text { SACKS }} &{9.09} &{9.8} &{17.02} &{910} \\
{\hline \text { NYLON }} &{29.55} &{29.41} &{12.77} &{6.06} \\
{\hline \text { TOT AL }} &{100} &{100} &{100} &{100} \\
$\hline
\end{tabular}

As shown in Table 3, carton, plastic, textile, glass and nylon dominated the waste stream, followed by rubber, tin and sacks. These data informed on the kind of materials used mostly by the inhabitants. These wastes all have potential for recycling if they are all sorted out from the source as done in developed nations. Table 4 shows the amount that could be generated from the sale of each recyclable material if harnessed. Averages of $0.58 \mathrm{~kg} /$ person/day of solid waste have been estimated to be generated in Nigeria (Sridhar and Adeoye, 2003). The total population of Ota by the 2006 census

David O. Olukanni, Oladipupo O. Akinyinka, Anthony N. Ede, Isaac. I. Akinwumi and Kolawole O. Ajanaku (2014), Journal of South African Business Research, DOI: 10.5171/2014.705695 
was estimated at 527,242 people. Therefore, the total approximate waste generated by the residents of Ota people is $0.58 \mathrm{~kg} /$ person/day $\times 527,242$ people $=305,800.36 \mathrm{~kg} /$ day.

The Nigerian currency ( $\#$ ) was deem fit in estimating the price for which the recyclable materials are bought. The currency is estimated at an approximate rate of $\$ 160$ and \$220 to a dollar (\$) and euro (€), respectively. The paper products are packaged in bales: 1 bale $=226.8 \mathrm{~kg}$. A bale of

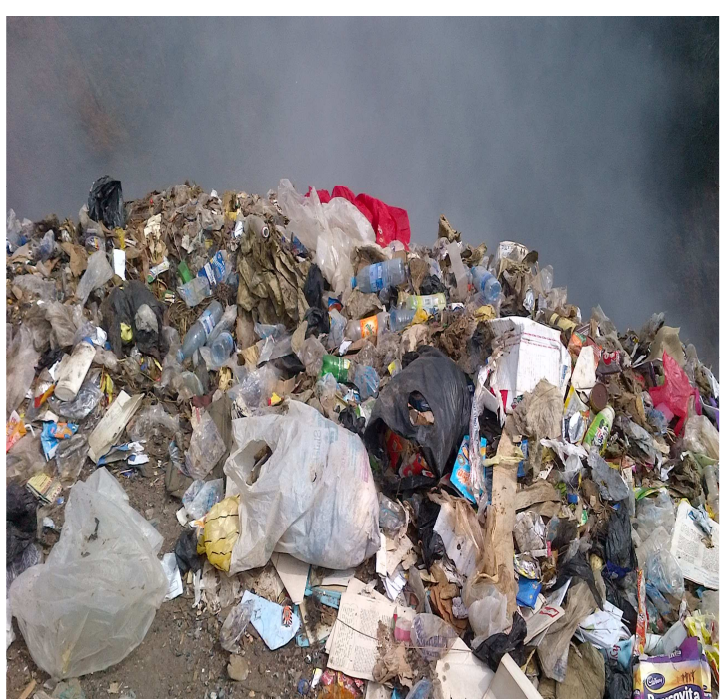

4 (a) waste paper and carton is sold for about $\$ 32$, 000 , while other items are sold for $\$ 30, \pm 30$, \#30 and \#40 for plastic, glass, Tin can, and Nylon, respectively. These prices were given by the respective local vendor who buys and packed the materials for sale to recycling plants and companies in Lagos, Nigeria. Figure 4 a shows the composition of potential recyclable waste stream that are indiscriminately dumped, while $4 \mathrm{~b}$ shows the waste being burnt at the dump site.

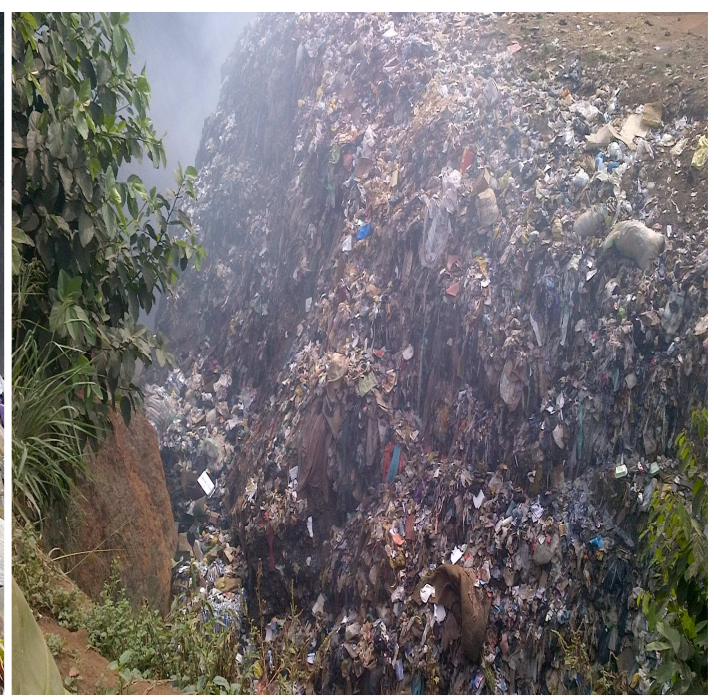

4 (b)

Figure 4 Composition of Waste at dumped and burnt at the dump site

Table 4 Representative Composition of Inorganic Waste in Ado-Odo Local Government

\begin{tabular}{|l|l|l|l|l|l|}
\hline Materials & $\begin{array}{l}\text { Average } \\
\text { Percent of } \\
\text { each item in } \\
\text { the waste } \\
\text { stream (\%) } \\
\text { waste } \\
\text { generation per } \\
\text { day (kg/day) }\end{array}$ & $\begin{array}{l}\text { Quantity of } \\
\text { sale of each } \\
\text { recyclable } \\
\text { material } \\
\text { (N/kg) }\end{array}$ & $\begin{array}{l}\text { Potential } \\
\text { Revenue/day of } \\
\text { the materials from } \\
\text { the waste stream } \\
\text { (N/day) }\end{array}$ & $\begin{array}{l}\text { Potential } \\
\text { Revenue/day } \\
\text { of the } \\
\text { materials from } \\
\text { the waste } \\
\text { stream } \\
\text { \$/day) }\end{array}$ \\
\hline Paper & 3.94 & 12048.28 & 35 & $421,689.80$ & 2635.56 \\
\hline Carton & 11.78 & 36023.28 & 35 & $1,260,814.80$ & 7880.09 \\
\hline Plastics & 11.48 & 35105.88 & 30 & $1,053,176.40$ & 6582.35 \\
\hline Textiles & 9.73 & 29754.38 & - & - & - \\
\hline Rubber & 8.87 & 27124.49 & - & - & - \\
\hline Glass & 14.19 & 43393.07 & 30 & $1,301,792.10$ & 8136.20 \\
\hline Tin Can & 9.32 & 28500.59 & 30 & $855,017.70$ & 5343.86 \\
\hline Sacks & 11.25 & 34402.54 & - & - & - \\
\hline Nylon & 19.45 & 59478.17 & 40 & $2,379,126.80$ & 14869.54 \\
\hline Total & 100 & 305800.36 & - & - & \\
\hline
\end{tabular}

David O. Olukanni, Oladipupo O. Akinyinka, Anthony N. Ede, Isaac. I. Akinwumi and Kolawole O. Ajanaku (2014), Journal of South African Business Research, DOI: 10.5171/2014.705695 
Table 4 shows that a significant amount of revenue could be generated from the recyclable materials if they are sorted from source. The other prices are not available

Table 5: Representative Composition of Organic Waste in Ado-Odo Local Government

\begin{tabular}{|lcccc|}
\hline LOCATION & $\begin{array}{c}\text { Iganmode } \\
\text { Site A }\end{array}$ & $\begin{array}{c}\text { Joju } \\
\text { Site B }\end{array}$ & $\begin{array}{c}\text { Ota Market } \\
\text { Site C }\end{array}$ & $\begin{array}{c}\text { Toll Gate } \\
\text { Site D }\end{array}$ \\
\hline MATERIAL & $\begin{array}{c}\text { Percentage } \\
(\%)\end{array}$ & $\begin{array}{c}\text { Percentage } \\
(\%)\end{array}$ & $\begin{array}{c}\text { Percentage } \\
(\%)\end{array}$ & $\begin{array}{c}\text { Percentage } \\
(\%)\end{array}$ \\
FOOD WASTE & 31.03 & 59.26 & 48.15 & 38.09 \\
AGRICULTRAL WASTE & 6.89 & 3.7 & 14.81 & 4.76 \\
OTHERS(DECOMPOSED) & 62.07 & 37.04 & 37.04 & 57.14 \\
TOTAL & 100 & 100 & 100 & 100 \\
\hline
\end{tabular}

Table 5 shows that food waste takes a significant amount of the organic waste stream, which when used appropriately could be of great benefit in composting. The remaining decomposed waste stream if annexed could be used to generate biogas or could serve as an alternative energy source.

\section{Discussion}

Approach to Current Waste Management Situation in the Study Location

Generally, waste management in the urban settings has been noted to be hindered by lack of technical and financial backing, inadequate human resources, absence of enabling legislations, and unintegrated policies (Agunwamba, 2001). The initiative for the private sector to participate in waste management is to strengthen the system. However, the participation of the private sector in managing waste has not been profitable because there is no regulation, and most companies are not being monitored by the government. Funding has made the waste management to experience a step back because solid waste management is very expensive. There is little financing even for private sector participation. Therefore, waste management agencies cannot meet the demand of collection effectively. It is imperative that the local government realizes that increasing environmental education and awareness are key factors to changing the current paradigm. Also, the initiative of minimizing waste through the concept of reduce, recycle, reuse and recover can be introduced. This concept impacts in terms of reducing wastes' quantity, and utilizing the waste with minimal handling to produce the same or other alternative products. This approach will ultimately reduce the high cost of investment in the extraction of virgin material thereby, saving energy and potentially saving money in the process.

\section{Condition of Collection Points and Disposal Sites}

Waste management's agency determines the frequency of the collection in the city. However, studies in other developing countries revealed that, inhabitants of affluent society have the ease of consistent home waste collection but on the other end, deprived communities have little or no waste collection services, leaving them to their fate, with waste surrounding their communities and homes. The collection in Ota is designed 
to be on a weekly basis but unfortunately, the weekly basis is not adhered to, which then causes the indiscriminate disposal around the waste bin and individuals hipping up bags of waste along the road side. Due to the numbers of waste bin and location, it would be suggested that the collection should be twice a week and consistency should be enforced. The population, consumption and frequency of waste generation have made it obvious

that the waste bins in Ota are not enough to serve the disposal need of the community. Other locations should be created for more generation point. The collection system is also not efficient due to the inadequate collection vehicle.

The solid waste collection system is the conventional hauled container system and there is no form of processing. The general practice in most parts of the metropolis has been dumping of refuse in the open and at road sides. This provides harborage for diseases causing organisms, bacteria, insects, and vermin. Some individuals use the waste bins provided by the local government as generation point. There is no form of on-site sorting of waste at the generation or collection point, and as such different waste are dumped. Smell is also given off at the collection points if quick removal of wastes is not done. Scattering the waste in the area next to the waste bin due to activity of scavengers causes degradation in the aesthetic quality of the environment.

The waste collection vehicle picks up the wastes and transfers them to the final disposal site. There is no house-to-house service, and in most cases people pack their waste in bag and sacks and place it by road sides which last for days before the local authorities come to pack them.

Cart pushers also dispose the waste collected at a certain fee from house-holds that do not have access to the provided waste bin. Because of the frequency of disposal, there is always spill of waste around the bin which is non-hygienic. The transportation is such that waste bins are taken directly to the dump site emptied and returned to their original location. The disposal site, owned by the local government, is a steep land whereby wastes disposed are pushed and burnt. This site emanates unpleasant odor and becomes a procreation ground for flies, rodent and pest. There are also categories of people referred to as street buyers and street finders who buy any reparable items including old cloths, furniture, waste paper, bottles and glass, and those who gather materials that have been overlooked by others.

\section{Wealth Generation through Recycling and Reuse}

Recycling measures are still faced with many problems such as lack of financial resources, collection and transportation facilities and lack of advanced technology. The quantity of waste needed to be collected, transported and disposed-off are cut down by recycling which ultimately extends the life of disposal facilities and saves resources for environmental agency. Oumarou et al. (2012) stated that recycling and the reuse potential of MSW is not only about removing waste from the environment and returning it as new products or raw material, it is also a tool of social integration and economic wellbeing. The public needs to be sensitized on the potential wealth that their inorganic and organic wastes contain. Ruzi (2001) expressed that recycling cuts down the quantity of waste that needs to be picked up, transported, and disposed of which ultimately extends the life of disposal facilities. Reuse of reclaimed material usually involves less energy than the utilization of virgin material. For instance, there is an overall net decrease of 3.6 metric tons of carbon dioxide emission for every ton of recycled paperboard packaging produced (ENVIS, 2010). In Ota, there is no form of sorting of the collected waste from the generation sources to the disposal site, but scavengers pick materials which are reused and the bulk of the waste that are burnt. A significant number of scavengers pack refuse for a fee and salvage any recyclable material 
from the waste stream before taking it to the final disposal site. Other repairable items (old furniture, waste paper, bottles and glass, and metal scraps) are bought by the scavengers in some cases. Nigeria has a large number of population, and a lot of employment can be generated through waste management processes of composting organic waste, and recycling inorganic waste. These will improve the quality of life aside attracting investments and generating employment opportunities

Waste materials such as paper, plastic, bottles and glass can be put back into the raw product stream as base material. Some scavengers go around the town pushing their trucks, and pay individuals who have some recyclable materials like metal scraps and plastics. Facilities could be provided where sorting of materials to be recycled is carried out. In this way, retrieval of materials would lessen the need to utilize natural resources directly, and may cut down emissions from extraction and processing of new products.

These could offset the benefits of recycling to some extent. For example, food from households is fed to animals, some are home composted and utilized to condition the soil while, others can be utilized to generate biogas. It is apparent that the local government takes responsibility for their waste and should begin to incorporate recycling and reuse into their solid waste management plans. Plastic can be recycled and reused depending on the quality. Recycling process of plastics involves washing, shredding, drying, wet grinding; extrusion, pelletizing and the final product is packaged and sold to consumers. Paper recycling saves the forest of trees which would produce new papers. It reduces the quantity of solid waste disposed, and the pollution also reduces during manufacturing because the fibers have been processed once. Adewuyi et al (2008) also added that since African wood species have been considered to have potentials for generating significant amount of potash, resources from wood- based raw materials industries could meet Nigeria's needs. Reuse of aluminum salvages valuable raw materials, energy, time and capital. It involves re-melting scrap aluminum after its initial production.

Compost/organic fertilizer can be obtained from the food waste by converting biowaste into organic fertilizer. This is an aerobic process whereby micro-organism decomposes biodegradable waste to produce organic fertilizer in the presence of ample oxygen. This waste has its usefulness rooted in fertilizer generation, which would be of great benefit and in fact cheap for farmers. Yusuf and Oyewumi (2008) expressed that the emergence of organic waste for the production of fertilizer and its potential use in the production of biogas has been on the increase. The potential for producing a huge amount of methane gas and other resources from solid wastes has been studied by various researchers in Nigeria (Pasquini and Alexander, 2004; Aina, 2006; Adewuyi et al., 2008).

\section{Conclusion}

Established on the findings of this study, the following propositions that would improve the management of municipal solid waste for residents in the study area are presented:

Environmental management of Ota metropolis should involve partnership of various stakeholders and consortium of all expertise in the entire sanitation process.

It is vital that resources for managing the waste are harnessed, and adequate consideration should be given to storage, separation/sorting, collection, intermediate transfer and mass transport to final disposal site. The frequency of collection and route planning for collection vehicle should be developed for the ease of collection from all generation point, and the public should be sensitized on the locations for discarding their waste. Absolute compliance with antilitter laws and regulations should be enforced. 
Public education campaigns should be developed to encourage public participation of sustainable waste management. This should be supported with stringent policies and enforcement of sanitation and laws to facilitate it.

Solid waste recycling should be combined with other solid waste management options to stop environmental decay. The public should be enlightened on the wealth inherent in their organic and inorganic wastes.

The government should encourage the advancement and acceptance of appropriate technologies for the conversion of organic waste to compost and support its markets for its function as soil conditioners.

All these can be accomplished through the encouragement of economical, resourceful and environmentally safe practices in managing municipal waste.

Acknowledgment

The authors are grateful to the community personnel for their contribution and cooperation in making the exercise a successful one. The management of Covenant University is also appreciated for providing enabling environment.

\section{References}

1. Abel, O A. (2009) An analysis of solid waste generation in a traditional African city: the example of Ogbomoso, Nigeria. Environment and Urbanization, SAGE Journals, 19(2): 527-537.

2. Adefemi. S O and Awokunmi, E E. (2009) The impact of municipal solid waste disposal in Ado- Ekiti metropolis, Ekiti-State, Nigeria, African Journal of Environmental Science and Technology Vol. 3 (8), pp. 186-189.

3. Adewumi, I K., Ogedengbe, M O., Adepetu, J A and Fabiyi, Y L. (2005) Planning organic fertilizer industries for municipal solid wastes management. Journal of Applied Sciences Research, 1(3): 285-291.
4. Adewuyi, G O., Obi-Egbedi, N O. and Babayemi, J O (2008) Evaluation of ten different African Wood species for potash production. International Journal of Physical Science, 3(3): 63-68.

5. Agunwamba, J C. (1998) Solid Waste Management in Nigeria: Problems and Issues. Environmental Management. Volume 22 (6): 849-856.

6. Agunwamba, J C. (2001) Waste Engineering and Management Tools. Immaculate Publications Ltd, Enugu, Nigeria.

7. Agunwamba, J C. (2003) Environmental Assessment: Analysis of Scavengers' Activities and Recycling in Some Cities of Nigeria. Environmental Management. Volume 32 (1):116-127.

8. Aina, O M. (2006) Wood waste utilization for energy generation. Proceedings of the International Conference on Renewable Energy for Developing Countries, 2006.

9. Akinro, A O. Ikumawoyi, O. B., Yahaya, 0 and Ologunagba, M.M. (2012) Environmental Impacts of Polyethylene Generation and Disposal in Akure City, Nigeria. Global Journal of Science Frontier Research Agriculture \& Biology. Volume 12 (3): 1.0

10. Babayemi, J O. and Dauda, K T. (2009) Evaluation of Solid Waste Generation, Categories and Disposal Options in Developing Countries: A Case Study of Nigeria. J. Appl. Sci. Environ. Manage. Vol. 13(3) $83-88$.

11. ENVIS NSWAI (2010) Urban Municipal Waste Management Newsletter 18(1)

Accessed at www.nswai.com. Site visited 04/09/2012

12. Imam, A., Mohammed, B., Wilson, D C. and Chessman, C R. (2008) Solid waste management in Abuja, Nigeria. Waste Management 28(2): 468-472. 
13. Kyessi, A and Mwakalinga, V. ( 2009). GIS Application in Coordinating Solid Waste collection: The Case of Sinza Neighborhood in Kinondoni Municipality, Dar es Salaam City, Tanzania. Unpublished Paper Presented in to Surveyors Key Role in Accelerated Development, Eilat, Israel, 3-8 May 2009.

14. Ogwueleka, T C. (2009) Municipal Solid Waste Characteristics and Management in Nigeria Iran. J. Environ. Health. Sci. Eng., Vol. $6(3): 173-180$

15. Olukanni, D $\mathrm{O}$ and Akinyinka, O M. (2012) Environment, Health and Wealth: Towards an analysis of municipal solid waste management in Ota, Ogun State, Nigeria. Presented at the International Conference on Clean Technology and Engineering Management, Covenant University, Ota, Nigeria, ICCEM (2012) 51 - 71.
16. Oumarou, M B., Dauda, M., Abdulrahim, A T., Abubakar, A B. (2012) Municipal Solid Waste Generation, Recovery and Recycling: a Case Study. World J of Engineering and Pure and Applied Sci. Vol. 2(5):143

17. Pasquini, $\mathrm{M} \mathrm{W}$. and Alexander, $\mathrm{M} \mathrm{J}$. (2004) Chemical properties of urban waste ash produced by open burning on the Jos plateau: implications for agriculture. Science of the Total Environment. 319(1-3): 225-240.

18. Ruzi, J A. (2001) Recycling overview and growth. In Lund H. F. (Ed): The McGraw Hill Recycling Handbook, Chapter 1, McGraw Hill, Inc, New York

19. Yusuf, R O and Oyewumi, M O. (2008). Qualitative assessment of methane generation potential for municipal solid wastes: a case study. Environmental Research Journal, Medwell Journals 2(4): 138-144. 